Is a Ukrainian Standard of the Russian Language on the Agenda?

Author(s): Michael A. Moser

Source: Kyiv-Mohyla Humanities Journal 7 (2020): 185-196

Published by: National University of Kyiv-Mohyla Academy

http://kmhj.ukma.edu.ua/ 


\title{
Is a Ukrainian Standard of the Russian Language on the Agenda?
}

\author{
Michael A. Moser \\ University of Vienna, \\ Institute for Slavic Studies
}

\begin{abstract}
This article discusses the pros and cons of the creation of a separate Ukrainian standard of the Russian language. Owing to the centralist and elitist history of the Russian standard language, the high variant of Russian that is used in Ukraine does not significantly differ from that of Russia, if at all. Low varieties, by contrast, are quite heterogeneous. The standardization of "Ukrainian Russian" would thus be very problematic at all stages: the selection of norms and their codification, the implementation and elaboration of the new norms. All these steps would not only require considerable funding; in the long run, it would also undermine the status of Ukrainian as Ukraine's sole state language.
\end{abstract}

Key Words: Ukrainian language, Russian language, Ukrainian Russian, pluricentric (polycentric) languages, pluricentrization, Ukrainian language policy.

\section{The Idea}

Over the past few years, a number of linguists, historians, and other intellectuals have come up with the idea that Ukraine should develop a separate Ukrainian standard variety of the Russian language. ${ }^{1}$ The advocates of that idea usually compare the

$1 \quad$ See Timothy Snyder, "Historian Snyder on Language, Zelenskyy and Vakarchuk," Hromadske international, July 7, 2019, https://en.hromadske.ua/posts/ukrainians-own-russian-but-dontadmit-it-historian-snyder; Tomasz Kamusella, "What's Next after Ukraine's New Language Law?," Harvard Ukrainian Studies (Opinion), July 17, 2019, accessed December 1, 2020, https:// www.husj.harvard.edu/news/opinion-whats-next-after-ukraines-new-language-law. The idea is not new: in early 2015, Andrii Kurkov, one of Ukraine's leading intellectuals (a bilingual Russia-born writer who writes most of his books in Russian), called for the establishment of an Institute of the Russian Language at the National Ukrainian Academy of Sciences, see Andrii Kurkov, "Zaraz ya ne mozhu pysaty. Priorytet uvahy—ne v uiavi, a na Donbasi [I Cannot Write Now. The Focus of My Attention Is Not on My Mind, but on Donbas]," accessed December 1, 2020, The Insider, January 12, 2015, http://www.theinsider.ua/art/andrii-kurkov-zaraz-ya-nemozhu-pisati-prioritet-uvagi--ne-v-uyavi-a-na-donbasi/. For an interesting article in the press see: Oleksandr Bielokobylskyi, "Rosiiska mova. Prybraty monopoliiu Moskvy? [The Russian Language. Should We Appropriate Moscow's Monopoly?]," Radio Svoboda, 3 o October 30, 2016, 
situation of the Russian language to that of other large languages which have developed into different national standard varieties in the course of centuries, such as English, Spanish, German, Arabic etc. ${ }^{2}$

On the one hand, it is obvious that Russian is used by a relatively large number of speakers in various countries, ${ }^{3}$ and some varieties of Russian differ from standard Russian according to patterns that are quite characteristic for certain countries outside the Russian Federation (most often, as a result of contacts with other languages of those

accessed December 1, 2020, https://www.radiosvoboda.org/a/28082746.html. For a response to recent calls to create a separate Ukrainian standard of the Russian language see Michael Moser, “Ukraine's New Language Law Doesn't Ban Russian but Ends the Discrimination of the Speakers of Ukrainian," Harvard Ukrainian Studies (Opinion), July 18, 2019, accessed December 1, 2020, https://www.husj.harvard.edu/news/opinion-ukraines-new-language-law-doesntban-russian-but-ends-the-discrimination-of-the-speakers-of-ukrainian. For recent scholarly approaches see Tomasz Kamusella, "Russian: A Monocentric or Pluricentric Language?" Colloquia Humanistica 5 (2016): 164-88, accessed December 1, 2020, https://doi.org/10.11649/ ch.2018.010 (with an excellent overview of the extant literature), or Salvatore Del Gaudio, "The Russian Language in Ukraine: Some Unsettled Questions About Its Status as a 'National' Variety," in Non-dominant Varieties of Pluricentric Languages. Getting the Picture. In Memory of Michael Clyne, ed. Rudolf Muhr (Wien: Peter Lang, 2012), 207-26; Salvatore Del Gaudio and Olga Ivanova, "Variation in the Non-dominant Variety of Russian in Ukraine: Extralinguistic and Intralinguistic Perspectives," Travaux du 1gème CIL / 19th ICL papers. Congrès International des Linguistes, Genève 20-27 Juillet 2013, ed. Département de Linguistique de l'Université de Genève, 1-19 (2013), accessed December 1, 2020, http://www.cilig.org/uploads/documents/ Variation_in_the_nondominant_variety_of_Russian_in_Ukraine_extralinguistic_and_ intralinguistic_perspectives.pdf; Jan Patrick Zeller and Dmitri Sitchinava, "The Russian language in Belarus and Ukraine," in The Soft Power of the Russian Language. Pluricentricity, Politics and Policies, eds. Arto Mustajoki, Elena Protassova, and Maria Yelenevskaya (London, New York: Routledge, 2019), 108-22.

2 For pluricentricity as a widespread phenomenon see Michael Clyne, Pluricentric Languages: Differing Norms in Different Nations (Berlin: Mouton de Gruyter, 1992); Pluricentric Languages and Non-Dominant Varieties Worldwide, vol. 1, Pluricentric Languages Across Continents: Features and Usage, ed. Rudolf Muhr (Frankfurt am Main: Peter Lang, 2016); Pluricentric Languages and Non-Dominant Varieties Worldwide: New Pluricentric Languages - Old Problems, eds. Rudolf Muhr and Benjamin Meisnitzer (Berlin: Peter Lang, 2018).

Kamusella, "Russian," 157, puts great emphasis on this fact: "Russian is an official or national language in seven states (Belarus, Kazakhstan, Kyrgyzstan, Russia, Tajikistan, Turkmenistan, and Uzbekistan), in five de facto states (Abkhazia, South Ossetia, Transnistria self-proclaimed "Donetsk People's" and "Luhansk People's Republics"), while considerable Russophone speech communities exist in six countries (Estonia, Israel, Latvia, Lithuania, Moldova, Ukraine). What is more, Russian remains an important foreign (second, L2) language of wider communication in at least four further states (Armenia, Azerbaijan, Georgia and Mongolia)." 
countries.${ }^{4}$ On the other hand, this indisputable fact does not necessarily imply that this variation should be utilized to create new standards of the Russian language. Even in those countries where Russian functions as an "official" or "co-official" language, there have been no serious attempts to standardize separate "national varieties" of Russian to date. In Ukraine, too, some advocates of the creation of a Ukrainian standard of the Russian language have highlighted typically Ukrainian interferemes in the Russian language to demonstrate that a Ukrainian variety of the Russian language or, briefly, "Ukrainian Russian," in fact already exists. ${ }^{5}$ The phenomenon of variation as such does, however, not yet establish the "polycentric" status of a language, even if it tends to follow nationwide patterns. In the end, "polycentricity" is first and foremost a result of language planning.

\section{The Linguistic Basis}

As far as the often-cited "Ukrainian Russian" vocabulary is concerned, it appears that the majority of the words are not convincing. Many of them are in fact names, such as biutovtsy, derived from the acronym BYuT Blok Yulii Tymoshenko (a Ukrainian political party), Ukrtelekom (a Ukrainian Internet provider), or grivna, cf. Ukrainian hryvnia (Ukraine's currency). As is expected, these names are only slightly adapted not only in Russian, but also in other languages, including English. The same applies to typically Ukrainian items and phenomena such as bandura (a musical instrument), the Ukrainian hopak (in standard Russian gopak), the Ukrainian rushnyk (an embroidered ritual cloth) (in Russian rushnik), or Ukrainian hrechanyky (buckwheat cakes) (in Russian grechaniki). In the end, it is also true of the Russian expression Verkhovnaia Rada "Supreme Council" (from Ukrainian Verkhovna Rada, instead of Russian Russian Verkhovnyi Sovet), which is sometimes used as a name in various languages too. ${ }^{6}$

4 See the articles and bibliographies collected in The Soft Power of the Russian Language.

$5 \quad$ Ukrainian interferemes in Ukrainian Russian have century-long traditions, see Michael

Moser, "Russisch in der Privatkorrespondenz ukrainischer Frauen aus dem 18. Jahrhundert," in Die russische Sprache und Literatur im 18. Jahrhundert: Tradition und Innovation-Russkii yazyk i literatura v XVIII veke: traditsiia i innovatsiia. Gedenkschrift für Gerta Hüttl-Folter, eds. Juliane Besters-Dilger and Fedor Poljakov (Frankfurt am Main: Peter Lang, 20o9), 289-322. In Soviet times, many Ukrainian features in Russian were often highlighted to "correct" typically Ukrainian "mistakes."

$6 \quad$ For all examples see Yurii Dorofeev, "Variantnye formy russkogo yazyka v sovremennom mire [Varying Forms of Russian in the Contemporary World]," in Yazyk i obshchestvo v sovremennoi Rossii i drugikh stranakh: Mezhdunarodnaia konferentsiia (Moskva, 21-24 iiunia 2010 g.): Doklady i soobshcheniia, eds. Viktor A. Vinogradov and Vida Yu. Mikhalchenko (Moscow: Institut yazykoznaniia RAN, 2010), 288-91; Lidiia S. Moskalenko, "Rasprostranenie proiavlenii variativnosti russkogo yazyka na Ukraine [The Spread of Variation Phenomena in the Russian Language in Ukraine]," Blog Lidii Moskalenko, uchitelia russkogo yazyka i literatury, April 6, 2014, accessed December 1, 2020, http://lida191o.blogspot.co.at/2014/o4/blog-post_6957. 
At first glance, the occurrence of certain other Ukrainian administrative terms in Russian Ukrainian, such as Ukrainian posvidchennia [probably, aside with the Russianized form posvidchene.-M. M.] instead of Russian udostoverenie "certificate, authentication," zaiava instead of zaiavlenie "declaration, announcement," ${ }^{7}$ etc. is a more serious argument that might in fact confirm the existence of a separate Ukrainian variant of the Russian language. However, although these words could probably be integrated into some fictitious Ukrainian standard of the Russian language they are at present rather occasional quotations from Ukraine's sole state language - this situation is quite typical for any contact of minority languages and official languages all across the world.

It cannot be denied, though, that a number of Ukrainian lexical items have apparently already reached the status of loans into the Russian language of many Ukrainians. A good example is gromada (from Ukrainian hromada "community") ${ }^{8}$ and its adjectival derivation gromadskii, as Kilian Gasslitter convincingly confirmed in a careful corpus analysis. ${ }^{9}$ Moreover, it is true that some Russian lexical items in fact tend to be used differently in Ukraine under the impact of their Ukrainian equivalents: gorodskoi golova "mayor," e. g., is used extremely rarely in Russian Russian, but quite often in Ukrainian Russophone texts, where it translates Ukrainian miskyi holova; derzhava [d'ırżavə] "state," e. g., is marked as a high-style expression in most varieties in Russian, whereas in Ukrainian Russian — under the impact of Ukrainian derzhava [deržava] it tends to be stylistically neutral ${ }^{10}$ (and should therefore usually be translated into Russian Russian as gosudarstvo).

The most frequently listed phonetic feature that is widely regarded as a marker of the Ukrainian variant of Russian is the pronunciation of fricative [C] or [ $\mathrm{h}$ ] instead of plosive $[\mathrm{g}] .{ }^{11}$ As is well known, however, the spirantization of $[\mathrm{g}]$ is not only typical

html; Lidiia S. Moskalenko, "Etapy vzaimodeistviia russkogo i ukrainskogo yazykov [Stages of Interaction Between the Russian and Ukrainian Languages]," Blog Lidii Moskalenko, uchitelia russkogo yazyka i literatury, April 6, 2014, accessed December 1, 2020, http://lida1910. blogspot.co.at/2014/o4/blog-post_6344.html; Lidiia S. Moskalenko, "Russko-ukrainskaia interferentsiia i problemy yazykovogo varirovaniia [Russian-Ukrainian Interference and Problems of Linguistic Variation]," Blog Lidii Moskalenko, uchitelia russkogo yazyka i literatury, April 6, 2014, accessed December 1, 2020, http://lida191o.blogspot.co.at/2014/o4/blog-post_6. html; Del Gaudio and Ivanova, "Variation"; see also Kilian Gasslitter, Gibt es eine ukrainische Varietät des Russischen? [Does a Ukrainian Variant of Russian Exist?] (unpublished diploma thesis: Vienna, 2016, accessed December 1, 2020, https:/usearch.univie.ac.at/primo-explore/ fulldisplay?docid=UWI_alma21312051370003332\&context=L\&vid=UWI\&lang=de_DE. Del Gaudio and Ivanova, "Variation," 7.

8 Moskalenko, "Russko-ukrainskaia interferentsiia."

9 Gasslitter, Gibt es eine ukrainische Varietät, 66-69.

10 Moskalenko, "Russko-ukrainskaia interferentsiia." The same is true of Belarusian Russian derzhava, see Boris Yu. Norman, "Russkii yazyk v sovremennoi Belarusi: praktika i norma [The Russian Language in Contemporary Belarus: Practice and norms]," Russkii yazyk 6 (2010), accessed December 1, 2020, http://rus.1september.ru/view_article.php?id=2010006o4. 
of Belarusian Russian, too, but also of southern Russian dialects. Other features that are sometimes listed include a somewhat different treatment of unstressed vowels (even including "non-reduction," according to Salvatore Del Gaudio), ${ }^{12}$ the absence of the devoicing of voiced consonants at the end of words (and, most likely, in front of unvoiced consonants?, or the pronunciation [-oŭ] instead of [-of] (in fact, more often [-əŭ] instead of [-əf]]), the palatalization of konferentsii, Shvetsiia, izoliatsiia, a less strongly palatalized pronunciation of $[\check{c}]<\mathrm{ch}>,{ }^{13}$ or the occurrence of $[\check{\mathrm{scc}}]$ instead of Russian [ ̌̌s’:],14 etc.

Most of the syntactic features that are often listed as typical of Ukrainian Russian are obviously little more than more or less frequent interferemes. ${ }^{15}$ Two of the most frequently cited features are particularly unconvincing: It is perfectly true that in Ukraine only $v$ Ukraine or, in Ukrainian, $v$ Ukraiini is regarded as acceptable (or, in this particular case, as "politically correct") - however, one can quite often hear and even read $v$ Ukraine in the Russian Federation too. ${ }^{16}$ Also, the use of the preposition pro with the accusative case instead of $o$ with the locative case in the meaning "(to talk) about" is not necessarily caused by the impact of Ukrainian; it is highly frequent in colloquial Russian in Russia as well. Other alleged syntactical features of Ukrainian Russian are no less questionable. ${ }^{17}$

All remarks notwithstanding, it is of course legitimate to ask whether these or other alleged features of Russian as spoken in Ukraine could be used to create a Russian standard of Ukrainian. At any rate, it is important to emphasize that 1 ) these features are by no means typical of all varieties of Russian that are spoken in Ukraine, 2) many Ukrainian speakers of Russian have a command of standard Russian that barely differs from that of speakers from the Russian Federation, if at all, and 3) many Russian speakers in the Russian Federation exhibit local features in their speech too (and they do not always (and do not always want to) speak perfect standard Russian, by the way, even if they have a command of it).18

$$
\text { Variability of the Russian Language in Ukraine]," Przeglad Wschodnioeuropejski } 2 \text { (2011): } 392 .
$$

13 Del Gaudio and Ivanova, "Variation," 6.

14 Moskalenko, "Rasprostranenie proiavlenii variativnosti."

15 Del Gaudio, "Aspekty variativnosti," 393-95. Del Gaudio is quite cautious at this point himself.

16 Even Russian President Vladimir Putin has occasionally used $v$ Ukraine, see Michael Moser, "Russischer Gaskrisendiskurs — Vladimir Putins Pressekonferenz vom 8. Januar 20o9," Studia Slavica Academiae Scientiarum Hungaricae 54.2 (2009): 271-315. Moreover, many Ukrainians use na Ukraiini/na Ukraine informal speech too, regardless of their political preferences.

17 This is confirmed by a careful corpus analysis in Gasslitter, Gibt es eine ukrainische Varietät, $87-92$.

18 Most researchers of "Ukrainian Russian" agree with this assessment, see, e. g., Del Gaudio, "Aspekty variativnosti," 388 : “[...] est' chast' russkoiazychnogo naseleniia, ne obiazatelno prinadlezhashchaia k ètnicheskim rossiianam, kotoraia sleduiet norme standartnogo russkogo yazyka Rossii; k nim otnosiatsia prepodavateli, intellektualy, uchenye, voennye vysokogo ranga, professionaly raznykh otraslei i t. d." ("there exists a part of the Russian-speaking population 
It might be true that the most characteristic variety of "Ukrainian Russian" is spoken by "the Russian-speaking population in the large industrial cities of the eastern and southeastern regions of Ukraine,"19 and it might make sense to study precisely these types of speech from various scholarly perspectives. But does a variety that is quite characteristic of these places - and, in fact, milieus - necessarily imply that a new Ukrainian standard of the Russian language should be created, and that this standard should be based precisely on these varieties? As I recently argued in an op-ed piece, "the high variety of Russian that is spoken in Ukraine differs from the Russian high variety of Russian only slightly, if at all," whereas "lower varieties are, by contrast, extremely diverse, and it is not likely that anybody who is in favor of the idea to raise the prestige of Russian in Ukraine would embrace a standard developed on the basis of these lower varieties" (including, of course, those of the eastern or southern cities of Ukraine). Moreover, it has not been clarified at all whether speakers of those low varieties (who often simply do not intend to use standard language) would be very fond of any newly established Russian standards themselves.

\section{The Expected Benefits}

The advocates of the creation of a Ukrainian standard of the Russian language usually put forward two major types of arguments that can be categorized as "primarily linguistic" on the one hand and "primarily political," on the other.

The "primarily linguistic" line of reasoning says, briefly, that 1) Russian is one of the larger languages of the world that is spoken - and even has an official status - in more than one country, 2) most languages of that type tend to be pluricentric, and consequently, 3) Russian should (almost inevitably) be pluricentrized. ${ }^{20}$

The "primarily political" arguments emphasize that 1 ) Russophone people outside the Russian Federation should not leave the standardization (and control) of the Russian language to the Russian Federation and its institutions, ${ }^{21} 2$ ) the pluricentrization of

that is not necessarily ethnically Russian and follows the norms of the Russian standard language of Russia, among them being instructors, intellectuals, scholars, high-ranking military persons, professionals of various branches, etc."). One could add at this point that 1 ) as long as Russian is not pluricentricized, "the" Russian standard language will necessarily be "the Russian language of Russia," and 2) in Russia itself, too, a more or less close adherence to the norms of the standard language is primarily typical of the listed societal groups.

19 Del Gaudio, "Aspekty variativnosti," 388.

$20 \quad$ Kamusella, "Russian." This approach is also typical of the volumes edited by Rudolf Muhr (see fn. 2).

21 See Kamusella, "Russian," 154: "From the perspective of sovereignty, this arrangement [the monocentric standardization of the Russian language.-M. M.] affords Moscow a degree of influence and even control over culture and language use in the countries where Russian is official. This fact was consciously noticed and evoked some heated discussions in Ukraine after the Russian annexation of the Ukrainian region of Crimea in 2014. However, thus far, the discussions have not translated into any official recognition of (let alone encouragement for) 
Russian is a powerful weapon against the (obviously wrong) Russkii mir-oriented "assumption that each 'native' (L1) Russian-speaker must be a member of the Russian nation [...]" (and its tragic political implications, namely the war in Eastern Ukraine), and 3) this pluricentrization would eventually lead to the "de-ethnization" of the Russian language. ${ }^{22}$

Although a variety of factors generally exert impact on the pluricentrization of languages, ${ }^{23}$ the entire issue is obviously not a primarily linguistic one, as demonstrated by the fact that even the "primarily linguistic" arguments eventually refer to political assumptions. We thus end up with the elementary question whether the pluricentrization of a certain language appears to be desirable for certain societal actors or not. As usually, this is a matter of both pros and cons, particularly regarding Ukraine.

\section{The Problems}

Since its genuine beginnings in the mid-18th century, the standardization of the Russian language has always been centered in the Russian Academy of Sciences (either in

state-specific varieties of the Russian language." See also Timothy Snyder's statement: "If you had your own version of the language with your own dictionary than you could allow people to tell whether a newspaper was from Russia or whether it was from Ukraine. And also, it would allow Ukrainians to express themselves in Russian in a way that was nevertheless not the same way as people speak in the Russian Federation. [...] If you officially had your own Ukrainian version of the Russian language that would be a very powerful argument against the Russian propaganda. You could say: no, actually, we are supporting the Russian language and you can make the following point, which is true: In Russia, there's no freedom of speech which means someone else has to take care of the Russian language. So we have freedom of speech, therefore, we are going to take care of the Russian language" (Snyder, "Historian Snyder").

22 Kamusella, "Russian," 155.

23 See Rudolf Muhr's catalogue: “[... 1: Occurrence: A certain language occurs in at least 2 nations that function as 'interacting centres,' [... 2: Linguistic distance (Abstand): The variety must have enough linguistic (and/or pragmatic) characteristics that distinguish it from others and by that can serve as a symbol for expressing identity and social uniqueness [...], 3: Status: The language must have an official status in at least 2 nations either as (a) state-language or (e. g. German in Austria and Germany); (b) co-state language (e. g. German, French and Italian in Switzerland) or at least as (c) regional language (e. g. German in Italy: South Tyrol, Catalan in France: Department Pyrénées-Orientales etc.). The language therefore must have official recognition that exceeds the status of a minority language as it otherwise cannot function as a norm setting centre [...], 4: Acceptance of pluricentricity: The language community must accept the status of its language as a pluricentric variety and consider it as part of its social / national identity [...], 5: Relevance for identity: The national norm has to be relevant to social identity and must be (to some degree) aware to the language community and lead' to at least some of its own (codified) norms." (Rudolf Muhr, "Linguistic Dominance and Non-dominance in Pluricentric Languages: A Typology," in Non-Dominant Varieties of Pluricentric Languages. Getting the Picture. In Memory of Michael Clyne, ed. Rudolf Muhr (Wien: Peter Lang, 2012), 29-30). 
St. Petersburg or in Moscow) and largely oriented toward elite varieties. ${ }^{24}$ Until the end of the First World War, due to the high level of illiteracy in the Russian Empire, a good command of the Russian standard language was thus largely limited to the rather narrow circles of Russian elites. In the course of decades and centuries, vernacular elements were increasingly introduced into standard Russian too, but even after Soviet language planners largely overcame widespread illiteracy, they did not really break up with the traditional centralist and elitist roots of Russian standardization ${ }^{25}$ that have largely persisted to date.

Although there is no doubt that these traditions could be theoretically reversed anytime, it is quite predictable that any attempts to establish any new and newly-oriented standards of Russian will inevitably lead to considerable societal dissent in practice. And one of the major questions is whether precisely Ukraine should embark to take such steps, despite the fact that 1 ) the whole issue has not really evoked great interest in the country to date, ${ }^{26}$ and 2) according to any of Ukraine's language laws after 1989, the status of Russian is confined to that of a regional or minority language, whereas polycentric varieties clearly tend to be "fully official" or state languages? ${ }^{27}$

The process of pluricentrization - i. e., of standardization in a genuine understanding - would require considerable intellectual and financial resources in any country that would take according steps. Namely, the standardization of a language is certainly not finalized with the selection and the codification of orthographic rules, a grammar, and a dictionary, which, in light of the country's traditions, would probably have to be provided (or at least supervised) by the National Academy of Sciences of Ukraine (or, more specifically, its Potebnia Institute of Linguistics). The following processes of implementation and ongoing elaboration, which would require great efforts in more societal spheres, including all educational and administrative institutions, the media, etc., would predictably prove to be the significantly greater burden. ${ }^{28}$

24 These were quite modest beginnings, by the way: Only 1,200 copies of Mikhail Lomonosov's Rossiiskaia grammatika (Russian Grammar) were published in St. Petersburg in 1857, and as few as 6 oo copies of the first volume of the Slovar Akademii Rossiiskoi (Dictionary of the Russian Academy) were printed as late as $1789-1794$.

For a good overview see Bernhard Comrie, Gerald Stone, and Maria Polinsky, The Russian Language in the Twentieth Century (New York: Oxford University Press, 1996).

26 Kamusella, "What's Next," refers to "the creation of the Ukrainian standard of the Russian language launched in 2015 with the Office of the President of Ukraine" (accessed December 1, 2020, https://petition.president.gov.ua/petition/15853). It should be emphasized that in the course of four months (see the list "Pidpysanty" ibid.), the petition found no more than 19 supporters (!).

27 For the situation up to 2013, see Michael Moser, Language Policy and the Discourse on Languages in Ukraine under President Viktor Yanukovych (Stuttgart: Ibidem, 2013).

28 Timothy Snyder argues in his recent interview: "I think of it in my own mind as 'Ukrainian State Institute of Russian Language and Culture,' if there was such a thing and we are talking about a thing that would cost a few million euros a year, we are talking about a building or two 
While according to recent polls (2019) about $77 \%$ of the citizens of Ukraine support the status quo of Ukrainian as the sole state language, ${ }^{29}$ it is predictable that any possible standardization of "Ukrainian Russian" would not only considerably distract the focus of Ukraine's linguistic debates from the Ukrainian language, - it would also, as I argued earlier, "inevitably lead to the rise of the prestige of the Russian language in Ukraine," "eventually add fuel to the idea that Russian should be recognized as the second state language of Ukraine and, in the long run, to the 'Belarusization' of Ukraine."30

The strengthening of the position of the Russian language in Ukraine would obviously occur to the detriment of Ukrainian, because the standardization of the country's sole state language - particularly its implementation - is notoriously underfinanced, and the Russian language has retained a dominant position in many spheres (especially, in the business sphere). Moreover, the introduction of official bilingualism would undoubtedly require considerable funding (in Canada, the costs of official bilingualism were estimated at 2.4 billion dollars a year in 2006, when Canada had a population of roughly 32.6 million). ${ }^{31}$ The example of Belarus, where official Belarusian-Russian "bilingualism" has in fact almost entirely ousted the Belarusian language from the public sphere, demonstrates in the most obvious way that only a strong position of the Ukrainian language in Ukraine will contribute to the linguistic diversity of Europe, whereas a strong position of Russian will not.

buildings or three buildings maybe, we are not talking about competing on the whole are (sic) of the country were (sic) talking about doing a very technical operation, which is standardizing a language that millions of people use" (Snyder, "Historian Snyder"). Tomasz Kamusella agrees that "a State Institute of Ukrainian Russian may be established as well" (Kamusella, "What's Next?"). One might mention at this point that at present, the Potebnia Institute of Linguistics at the National Ukrainian Academy of Sciences is located not in one or two or three buildings, but in fact on only one floor of the building on Hrushevskyi Street 4 (moreover, the Institute is dealing with many more languages, not just Russian). The same applies, by the way, to the "Institute of the Ukrainian Language." 11 per cent of these 77 per cent contend that Russian should have an official status in some regions of Ukraine, whereas 21 per cent believe that both Ukrainian and Russian should be state languages, see "Stan ukrainskoi movy. Shchorichnyi monitorynh: pislia splesku vykorystannia ukrainskoi na telebachenni i v posluhakh, u tsykh sferakh znovu zrosla chastka rosiiskoi [The State of the Ukrainian Language. Annual Monitoring: After a Boom of Ukrainian Language Use on TV and in the Service Sector, the Amount of Russian Has Again Grown in These Spheres]," Teksty.org.ua, November 8, 2019, accessed December 1, 2020, http://texty.org. ua/pg/article/editorial/read/9786o/Stan_ukrajinskoji_movy_Shhorichnyj_monitoryng_pisla_ splesku?a_srt=2. Moser, "Ukraine's New Language Law."

31 François Vaillancourt, Olivier Coche, Marc Antoine Cadieux, and Jamie Lee Ronson, Official Language Policies of the Canadian Provinces - Costs and Benefits in 2006 (Fraser Institute, 2012), xii, accessed December 1, 2020, https://www.fraserinstitute.org/sites/default/files/official-language-policies-of-canadian-provinces-rev.pdf. 


\section{Conclusion}

The ongoing calls to establish a separate Ukrainian standard of the Russian language are based on debatable and questionable arguments. They tend to underestimate that the genuine standardization of a language requires considerable efforts and would inevitably raise the prestige and status of Russian in Ukraine to the detriment of Ukrainian. While "Ukrainian Russian" would predictably differ from the standard Russian language of Russia only slightly, the new status of the Russian language in Ukraine would in the long run probably undermine the status of Ukraine's sole state language.

\section{Bibliography}

Bielokobylskyi, Oleksandr. "Rosiiska mova. Prybraty monopoliiu Moskvy? [The Russian Language. Should We Appropriate Moscow's Monopoly?]." Radio Svoboda. October 30, 2016. https://www.radiosvoboda.org/a/28082746.html.

Clyne, Michael. Pluricentric Languages: Differing Norms in Different Nations. Berlin: Mouton de Gruyter, 1992.

Comrie, Bernhard, Gerald Stone and Maria Polinsky. The Russian Language in the Twentieth Century. New York: Oxford University Press, 1996.

Del Gaudio, Salvatore. "Aspekty variativnosti russkogo yazyka v Ukraine [Aspects of the Variability of the Russian Language in Ukraine]." Przeglad Wschodnioeuropejski 2 (2011): 383-97.

Del Gaudio, Salvatore. "The Russian Language in Ukraine: Some Unsettled Questions About Its Status as a 'National' Variety." In Non-Dominant Varieties of Pluricentric Languages. Getting the Picture. In Memory of Michael Clyne, edited by Rudolf Muhr, 207-26. Wien: Peter Lang, 2012.

Del Gaudio, Salvatore and Olga Ivanova. "Variation in the Non-Dominant Variety of Russian in Ukraine: Extralinguistic and Intralinguistic Perspectives." Travaux du 19ème CIL / 19th ICL papers. Congrès International des Linguistes, Genève 20-27 Juillet 2013, edited by the Département de Linguistique de l'Université de Genève, 1-19, 2013. Accessed December 1, 2020. http://www.cilig.org/uploads/documents/ Variation_in_the_nondominant_variety_of_Russian_in_Ukraine_extralinguistic_ and_intralinguistic_perspectives.pdf.

Dorofeev, Yurii A. "Variantnye formy russkogo yazyka v sovremennom mire [Varying Forms of Russian in the Contemporary World]." In Yazyk $i$ obshchestvo $v$ sovremennoi Rossii i drugikh stranakh: Mezhdunarodnaia konferentsiia (Moskva, 21-24 iiunia 2010 g.): Doklady i soobshcheniia, edited by Viktor A. Vinogradov and Vida Iu. Mikhalchenko, 288-91. Moscow: Institut yazykoznaniia RAN, 2010.

Gasslitter, Kilian. Gibt es eine ukrainische Varietät des Russischen? Unpublished diploma thesis. Vienna, 2016. Accessed December 1, 2020. https://usearch.univie.ac.at/primo-explore/fulldisplay?docid=UWI_ alma21312051370003332\&context=L\&vid=UWI\&lang=de_DE. 
Kamusella, Tomasz. "Russian: A Monocentric or Pluricentric Language?" Colloquia Humanistica 7 (2018): 164-88. https://doi.org/10.11649/ch.2018.o10.

Kamusella, Tomasz. “What's Next after Ukraine's New Language Law?" Harvard Ukrainian Studies (Opinion). July 17, 2019. https://www.husj.harvard.edu/news/ opinion-whats-next-after-ukraines-new-language-law.

Kurkov, Andrii. "Zaraz ya ne mozhu pysaty. Priorytet uvahy—ne v uiavi, a na Donbasi [I Cannot Write Now. The Focus of My Attention Is Not on My Imagination, But on Donbas]." The Insider. January 12, 2015. http://www.theinsider.ua/art/andrii-kurkov-zaraz-ya-ne-mozhu-pisati-prioritet-uvagi--ne-v-uyavi-a-na-donbasi/.

Moser, Michael. "Russischer Gaskrisendiskurs — Vladimir Putins Pressekonferenz vom 8. Januar 2009 [Russian Gas Crisis Discourse — Vladimir Putin's Press Conference of 8 January 2009]." Studia Slavica Academiae Scientiarum Hungaricae 54.2 (2009): 271-315.

Moser, Michael. "Russisch in der Privatkorrespondenz ukrainischer Frauen aus dem 18. Jahrhundert." In Die russische Sprache und Literatur im 18. Jahrhundert: Tradition und Innovation - Russkii yazyk i literatura v XVIII veke: traditsiia i innovatsiia. Gedenkschrift für Gerta Hüttl-Folter, edited by Juliane Besters-Dilger and Fedor Poljakov, 289-322. Frankfurt am Main: Peter Lang, 2009.

Moser, Michael. Language Policy and the Discourse on Languages in Ukraine under President Viktor Yanukorych. Stuttgart: Ibidem, 2013.

Moser, Michael. “Ukraine's New Language Law Doesn't Ban Russian but Ends the Discrimination of the Speakers of Ukrainian." Harvard Ukrainian Studies (Opinion). July 18, 2019. https://www.husj.harvard.edu/news/opinion-ukrainesnew-language-law-doesnt-ban-russian-but-ends-the-discrimination-of-thespeakers-of-ukrainian.

Moskalenko, Lidiia S. "Rasprostranenie proiavlenii variativnosti russkogo yazyka na Ukraine [The Spread of Variation Phenomena in the Russian Language in Ukraine]." Blog Lidii Moskalenko, uchitelia russkogo yazyka i literatury. April 6, 2014. http://lida191o.blogspot.co.at/2014/o4/blog-post_6957.html.

Moskalenko, Lidiia S. "Etapy vzaimodeistviia russkogo i ukrainskogo yazykov [Stages of Interaction Between the Russian and Ukrainian Languages].” Blog Lidii Moskalenko, uchitelia russkogo yazyka i literatury. April 6, 2014. http://lida191o. blogspot.co.at/2014/04/blog-post_6344.html.

Moskalenko, Lidiia S. "Russko-ukrainskaia interferentsiia i problemy yazykovogo varirovaniia [Russian-Ukrainian Interference and Problems of Linguistic Variation]." Blog Lidii Moskalenko, uchitelia russkogo yazyka i literatury. April 6, 2014. http://lida191o.blogspot.co.at/2014/o4/blog-post_6.html.

Muhr, Rudolf. "Linguistic Dominance and Non-Dominance in Pluricentric Languages: A Typology." In Non-Dominant Varieties of Pluricentric Languages. Getting the Picture. In Memory of Michael Clyne, edited by Rudolf Muhr, 23-48. Wien: Peter Lang, 2012. 
Muhr, Rudolf, and Benjamin Meisnitzer, eds. Pluricentric Languages and Non-Dominant Varieties Worldwide: New Pluricentric Languages - Old Problems. Berlin: Peter Lang, 2018.

Muhr, Rudolf, ed. Pluricentric Language and Non-Dominant Varieties Worldwide. Vol. 1. Pluricentric Languages across Continents: Features and Usage. Frankfurt am Main: Peter Lang, 2016.

Norman, Boris Yu. "Russkii yazyk v sovremennoi Belarusi: praktika i norma [The Russian Language in Contemporary Belarus: Practice and Norms]." Russkii yazyk 6 (2010). Accessed December 1, 2020. http://rus.1september.ru/view_article. php?id=2010006o4.

Snyder, Timothy. "Historian Snyder on Language, Zelenskyy and Vakarchuk." Hromadske international. July 7, 2019. https://en.hromadske.ua/posts/ukrainians-ownrussian-but-dont-admit-it-historian-snyder.

"Stan ukrainskoi movy. Shchorichnyi monitorynh: pislia splesku vykorystannia ukrainkoi na telebachenni i v posluhakh, u tsykh sferakh znovu zrosla chastka rosiiskoi [The State of the Ukrainian Language. Annual Monitoring: After a Boom of Ukrainian Language Use on TV and in the Service Sector, the Amount of Russian Has Again Grown in These Spheres].” Teksty.org.ua. November 8, 2019. http://texty. org.ua/pg/article/editorial/read/9786o/Stan_ukrajinskoji_movy_Shhorichnyj_ monitoryng_pisla_splesku?a_srt=2.

Vaillancourt, François et al. Official Language Policies of the Canadian Provinces - Costs and Benefits in 2006. Fraser Institute, 2012. Accessed December 1, 2020. https:// www.fraserinstitute.org/sites/default/files/official-language-policies-of-canadian-provinces-rev.pdf.

Zeller, Jan Patrick und Dmitri Sitchinava. "The Russian Language in Belarus and Ukraine." In The Soft Power of the Russian language. Pluricentricity, Politics and Policies, edited by Arto Mustajoki, Elena Protassova and Maria Yelenevskaya, 10822. London, New York: Routledge, 2019.

Michael Moser (born 1969 in Linz, Austria) is Professor of Slavic Philology at the University of Vienna, Pázmány Péter Catholic University (Budapest), and the Ukrainian Free University (Munich). His major field of interest is the history of Slavic languages, with a focus on Ukrainian, Russian, and Polish. His more recent publications include New Contributions to the History of the Ukrainian Language (Edmonton; Toronto: Canadian Institute of Ukrainian Studies Press, 2016) and Language Policy and the Discourse on Languages in Ukraine under President Viktor Yanukovych (25 February 2010-28 October 2012) (Stuttgart: Ibidem Press, 2013). 